Article

\title{
Functional Characterization of Porcine NK-Lysin: A Novel Immunomodulator That Regulates Intestinal Inflammatory Response
}

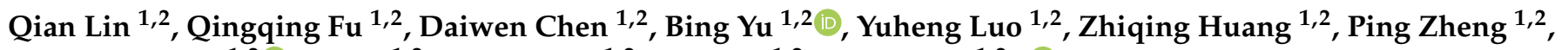 \\ Xiangbing Mao ${ }^{1,2} \mathbb{D}_{\text {, Jie Yu }}{ }^{1,2}$, Junqiu Luo ${ }^{1,2}$, Hui Yan ${ }^{1,2}$ and Jun $\mathrm{He}^{1,2, * \mathbb{D}}$ \\ 1 Institute of Animal Nutrition, Sichuan Agricultural University, Chengdu 611130, China; \\ linqian@stu.sicau.edu.cn (Q.L.); fqq0679@163.com (Q.F.); chendwz@sicau.edu.cn (D.C.); \\ ybingtian@163.com (B.Y.); luoluo212@126.com (Y.L.); z.q.huang@163.com (Z.H.); zpind05@163.com (P.Z.); \\ acatmxb2003@163.com (X.M.); jerryyujie@163.com (J.Y.); luojunqiu@163.com (J.L.); \\ yan.hui@sicau.edu.cn (H.Y.) \\ 2 Key Laboratory of Animal Disease-Resistant Nutrition, Chengdu 611130, China \\ * Correspondence: hejun8067@163.com; Tel.: +86-28-8629-1781; Fax: +86-28-8629-0922
}

check for updates

Citation: Lin, Q.; Fu, Q.; Chen, D.; Yu, B.; Luo, Y.; Huang, Z.; Zheng, P.; Mao, X.; Yu, J.; Luo, J.; et al. Functional Characterization of Porcine NK-Lysin: A Novel Immunomodulator That Regulates Intestinal Inflammatory Response. Molecules 2021, 26, 4242. https:// doi.org/10.3390/molecules26144242

Academic Editor: Simona Concilio

Received: 17 June 2021

Accepted: 9 July 2021

Published: 13 July 2021

Publisher's Note: MDPI stays neutral with regard to jurisdictional claims in published maps and institutional affiliations.

Copyright: (c) 2021 by the authors. Licensee MDPI, Basel, Switzerland. This article is an open access article distributed under the terms and conditions of the Creative Commons Attribution (CC BY) license (https:/ / creativecommons.org/licenses/by/ $4.0 /)$.

\begin{abstract}
Porcine NK-Lysine (PNKL) is a new antimicrobial peptide (AMP) identified in the small intestine. In this study, PNKL protein was obtained through heterologous expression in Escherichia coli and was estimated by SDS-PAGE at $33 \mathrm{kDa}$. The antibacterial activities of PNKL were determined using various bacterial strains and showed broad-spectrum antimicrobial activity against Gramnegative and Gram-positive bacteria. Furthermore, E. coli K88-challenged IPEC-J2 cells were used to determine PNKL influences on inflammatory responses. Hemolytic assays showed that PNKL had no detrimental impact on cell viability. Interestingly, PNKL elevated the viability of IPEC-J2 cells exposure to E. coli K88. PNKL significantly decreased the cell apoptosis rate, and improved the distribution and abundance of tight junction protein ZO-1 in IPEC-J2 cells upon E. coli K88-challenge. Importantly, PNKL not only down regulated the expressions of inflammatory cytokines such as the IL-6 and TNF- $\alpha$, but also down regulated the expressions of NF- $\mathrm{B}$, Caspase3, and Caspase9 in the E. coli K88-challenged cells. These results suggest a novel function of natural killer (NK)-lysin, and the anti-bacterial and anti-inflammatory properties of PNKL may allow it a potential substitute for conventionally used antibiotics or drugs.
\end{abstract}

Keywords: antimicrobial peptide; hemolytic activity; MIC; Porcine NK-Lysin

\section{Introduction}

Enterotoxigenic Escherichia coli (ETEC) is one of the main pathogens causing diarrhea in newborn neonatal animals, which causes huge economic losses in the livestock industry [1]. Infection of a newborn with ETEC frequently associate with severe watery diarrhea, rapid dehydration, and even death [2]. ETEC binds to interaction with the small intestinal mucosa by adhering to epithelial cells and then multiplies in the intestine, which subsequently produces enterotoxins that act on the intestine and lead to the secretion of large amounts of fluid in the small intestinal liquid, electrolytes, and causing diarrhea [3]. Currently, antibiotics and other chemical drugs are widespread therapeutic regimen to treat the ETEC infection. However, the long-term or over-dose utilization of complex antibiotics not only causes pathogen resistance and mutation, but also weakens the role of antibiotics or intensely accumulates in the body, thereby inducing gastrointestinal microbiota disorder, and causing a variety of diseases [4-6]. Therefore, substitutes for conventionally used antibiotics have attracted extensive research attention worldwide.

The most widely studied alternatives include probiotics, prebiotics, enzymes, acidifiers, plant extracts, and nutraceuticals such as copper and zinc. Antimicrobial peptides (AMPs) are clusters of immune-related peptides/proteins that can protect the host from 
pathogen infections $[7,8]$. It is an essential part of the internal defense of innate immunity of animal and plant kingdom and widespread in natures [9]. Antimicrobial peptides have a broad spectrum of antibacterial activities, as they can kill bacteria by permeating their membranes $[10,11]$. Although the antibacterial activity of AMPs against a specific pathogen is normally weaker than several conventionally used antibiotics, one of their major advantages is the ability to kill multidrug-resistant bacteria at relatively low concentrations [12]. Moreover, AMPs may involve multiple mechanism of bacteriostasis [13]. In addition to their antibacterial activity, AMPs have also been found to act as novel agents against bacterial biofilms and immunomodulators of the host immune system. For instance, catestatin has a close interaction with the neuroendocrine system and the immune system, which can activate human mast cells [14]. Ocellatin peptides is believed to inhibit the biofilm formation or to eradicate established ones [15]. Moreover, AMPs can regulate the secretion of inflammatory factors. For instance, the alpha-melanocyte stimulating hormone ( $\alpha$-MSH) reduces the concentration of proinflammatory mediators through the induction of cyclic adenosine monophosphate (cAMP) and inhibition of the nuclear factor $\kappa \beta$ (NF- $k \beta$ ), thus protecting the brain and peripheral organs from inflammatory disorders [16].

Natural killer (NK)-lysin, a member of saponin-like protein family [17], is a 9-kDa cationic protein which originally isolated from pig intestinal tissue and used as an effector peptide of cytotoxic T lymphocytes and NK cells [18]. In 1995, the porcine NK-lysin was firstly isolated from swine intestinal tissues [5]. Previous studies demonstrated that NK-lysin has a broad spectrum of antimicrobial activity including against bacteria, fungi, parasite, mycoplasma, and virus [19-21]. NK-lysin and its derivatives have been found to kill a variety of tumor cells, but harmless to erythrocytes [22-25]. Meanwhile, more and more evidence shows that AMPs can be used as key factors in immune regulation besides antibacterial and antiviral activities [26]. A previous study indicated that the AMPs can also act as an immunomodulator for mammals [8]. For instance, the porcine $\beta$-defensin (PBD) 2 was found to attenuate inflammation and mucosal lesions in dextran sodium sulfate-induced colitis [9].

In the present study, we describe the cloning and expression of PNKL gene by $\mathrm{pET}$ expression vector in E. coli Rosetta (DE3) by using a heterologous expression system. Moreover, the antimicrobial and anti-inflammatory activities of the PNKL protein were fully explored. This study not only reveals novel functions of the AMPs, but will also facilitate the development of substitutes for conventionally using antibiotics or drugs.

\section{Results}

\subsection{Comparison of the PNKL Nucleotide Sequences}

Blast analysis of the synthesized PNKL sequence was performed by using the DNAMAN 8.0. Results showed that the synthesized PNKL sequence was consistent with the published sequence (Supplementary Materials Figure S1). Both contained a 390-bp open reading frame, which encoded a 145 -amino acid PNKL mature protein. Structural analysis using the "SWISS model" showed that the PNKL protein was composed of 5 alpha helices (Figure 1A). Amino acid sequence analysis showed that the amino acid sequence of PNKL was highly conserved (Figure 1B). The Porcine NK-Lysin sequence was more than 70.75\% identical to the sequences obtained from Ovis aries, Bos Taurus, and Bos mutus. Phylogenetic tree analysis showed that the Porcine NK-Lysin was close to Ovis aries (Figure 1C).

\subsection{Expression and Purification of the Recombinant PNKL}

The PNKL gene with two designated restriction enzyme sites (EcoRI/NotI) was artificially synthesized. The two restriction enzyme sites allowed directional cloning of the PNKL gene into the pET32a expression vector. A 404-bp fragment was observed after double digestion of recombinant plasmid with the two restriction enzymes (Figure S2A). The recombinant plasmids were transformed into the E. coli Rosetta (DE3) and the positive clones were selected by PCR (Figure S2B). The most desired strain was chosen for small-scale induction by using $0.5 \mathrm{mmol} / \mathrm{L}$ IPTG at $28^{\circ} \mathrm{C}$. We found that the induction 
time significantly affected the expression level. As shown in Figure 2A, the E. coli achieved a maxima yield of the PNKL protein after $6 \mathrm{~h}$ induction (more than $250 \mu \mathrm{g} / \mathrm{mL}$ ). The molecular weight of recombinant PNKL was estimated by SDS-PAGE to be $33 \mathrm{kDa}$ (Figure 2A,B). The crude protein collected from ultrasonically-disrupted bacteria was purified by using $\mathrm{Ni2}{ }^{+}$-IDA affinity chromatography (Figure 2B).

A

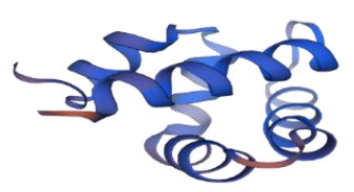

C

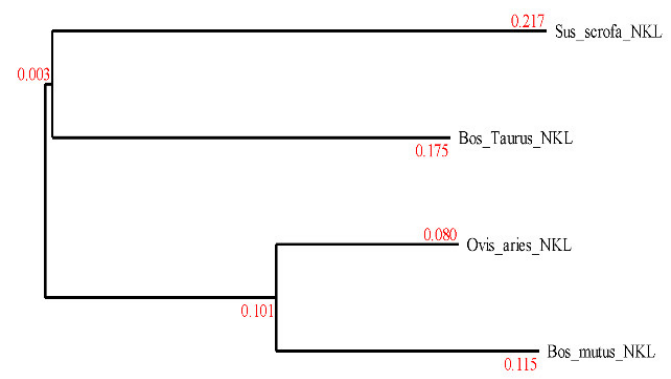

B

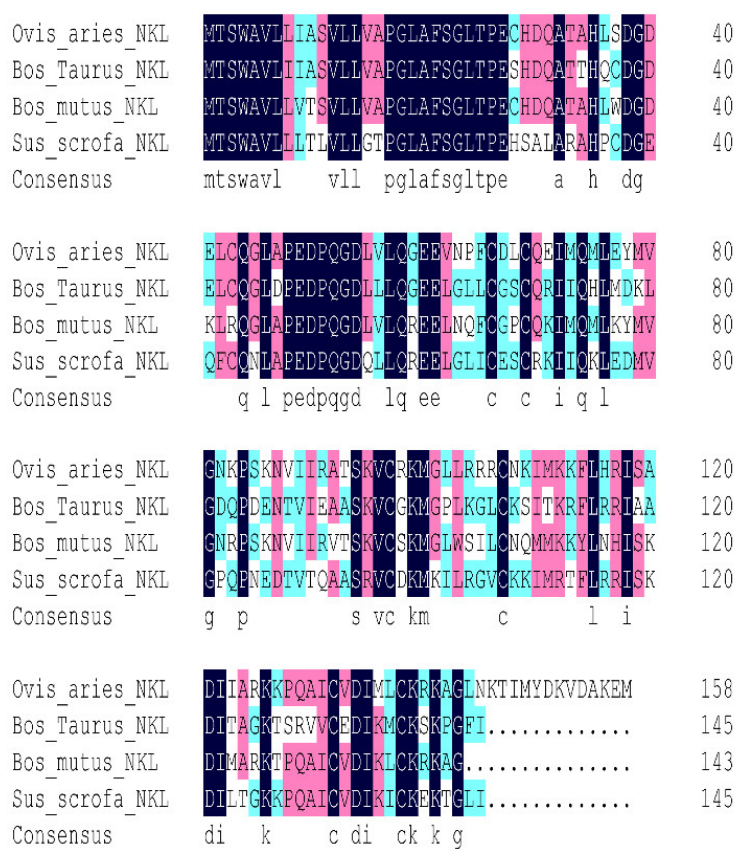

Figure 1. Phylogenetic analysis of Porcine NK-Lysin. (A), prediction model of PNKL; (B), phylogenetic analysis of PNKL in Sus scrofa, Ovis aries, Bos Taurus, and Bos mutus were performed by DNAMAN 8.0; (C), amino acid sequences of PNKL in Sus scrofa, Ovis aries, Bos Taurus, and Bos mutus were aligned by DNAMAN 8.0.

\subsection{Antibacterial Activity of the PNKL}

The antibacterial activities of PNKL was investigated by using Gram-negative and Gram-positive bacteria strains. As shown in Table 1, PNKL showed strong antibacterial activity against Gram-negative bacteria such as the E. coli K88 with a MIC of $4 \mu \mathrm{g} / \mathrm{mL}$. PNKL also showed antibacterial activity against the $S$. typhimurium (with a MIC of $8 \mu \mathrm{g} / \mathrm{mL}$ ). Moreover, the PNKL showed strong antibacterial activities against Gram-positive bacteria such as the $S$. aureus with a MIC of $2 \mu \mathrm{g} / \mathrm{mL}$. PNKL also showed antibacterial activity against the B. subtilis (with a MIC of $8 \mu \mathrm{g} / \mathrm{mL}$ ).

Table 1. MIC of PNKL produced by E. coli Rosetta (DE3).

\begin{tabular}{cc}
\hline Strain & MIC $(\mu \mathrm{g} / \mathrm{mL})$ \\
\hline Gram-negative bacteria & 32 \\
E. coli DH5 $\alpha$ 32 & 4 \\
Pathogenic E. coli K88 & 8 \\
Salmonella typhimurium CICC14028 & \\
Gram-positive bacteria & 16 \\
Streptococcus & 2 \\
Staphylococcus aureus CICC23656 & 8 \\
Bacillus subtilis & \\
\hline
\end{tabular}

\subsection{Hemolytic Activity of the PNKL}

Erythrocytes were collected from fresh porcine blood and incubated with different concentrations (0-256 mg/L) of PNKL for $1 \mathrm{~h}$. As compared to the TritonX-100, the PNKL showed no significant hemolytic activity at all concentrations (Figure 3). 


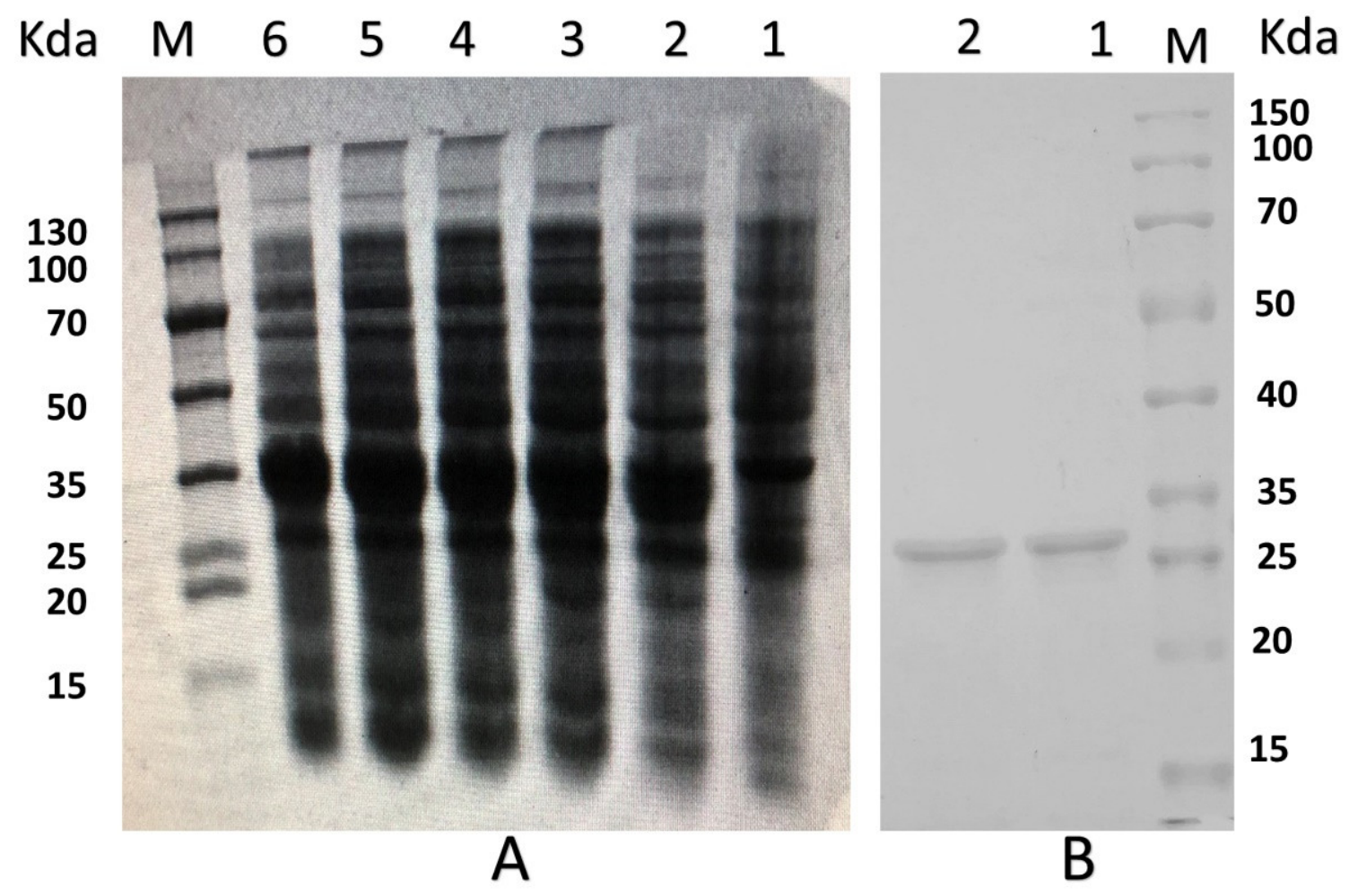

Figure 2. SDS-PAGE analysis of PNKL produced by E. coli Rosetta. (A), SDS-PAGE of PNKL from E. coli Rosetta. M protein markers (DL $130 \mathrm{kDa}$ ), Lane 1, E. coli Origami B (DE3)-pET32a (+) (non-induced), Lane 2, E. coli Origami B (DE3)-pET32a (+) induced by $1 \mathrm{mmol} / \mathrm{L} \mathrm{IPTG} \mathrm{for} 2 \mathrm{~h}$ at $28^{\circ} \mathrm{C}$, Lane 3, E. coli Origami B (DE3)-pET32a (+) induced by $1 \mathrm{mmol} / \mathrm{L}$ IPTG for $4 \mathrm{~h}$ at $28^{\circ} \mathrm{C}$, Lane 4 , E. coli Origami B (DE3)-pET32a (+) induced by $1 \mathrm{mmol} / \mathrm{L} \mathrm{IPTG} \mathrm{for} 6 \mathrm{~h}$ at $28^{\circ} \mathrm{C}$, Lane 5, E. coli Origami B (DE3)-pET32a (+) induced by $1 \mathrm{mmol} / \mathrm{L}$ IPTG for $8 \mathrm{~h}$ at $28^{\circ} \mathrm{C}$, Lane 6, E. coli Origami B (DE3)-pET32a (+) induced by $1 \mathrm{mmol} / \mathrm{L}$ IPTG for $10 \mathrm{~h}$ at $28^{\circ} \mathrm{C}$; (B), Purification of PNKL. M protein markers (DL $150 \mathrm{kDa}$ ), Lane 1-2 PNKL purified by Ni 2+ -IDA affinity chromatography.

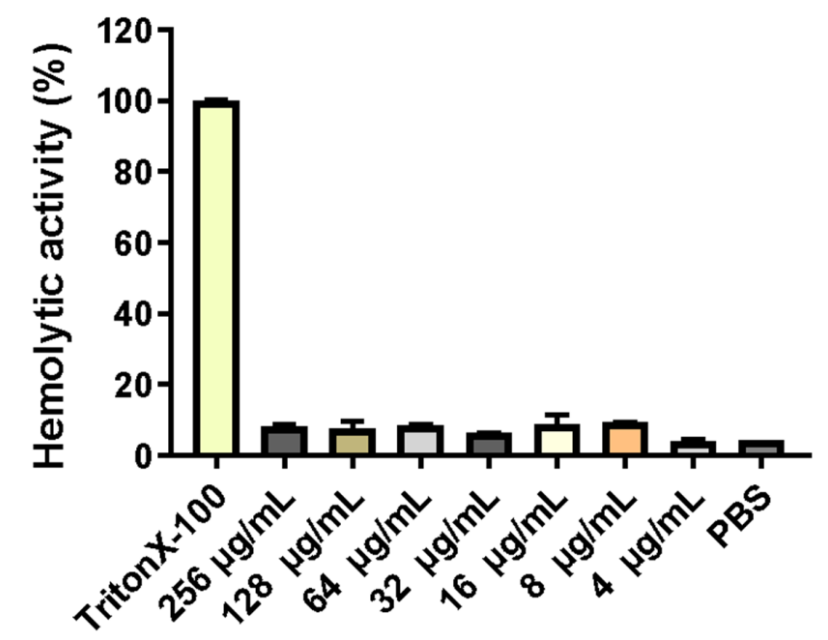

Figure 3. Hemolytic activity of recombinant of PNKL. PNKL $256 \mu \mathrm{g} / \mathrm{mL}$ PNKL, Triton X-100 0.1\% Triton X-100, PBS 10 Mm PBS (pH 7.3).

2.5. Effect of PNKL on Cell Viability, Apoptosis, and Localization of ZO-1 Protein in IPEC-J2 Cells Exposure to E. coli $\mathrm{K} 88$

As shown in Figure 4, E. coli K88 challenge decreased the viability of the IPEC-J2 cells. However, PNKL treatment elevated the cell viability. As compared to the control group, E. coli K88 challenge significantly elevated the apoptosis rates in the IPEC-J2 cells (Figure 5). However, PNKL treatment significantly decreased the early apoptosis and total 
apoptosis rates in the E. coli K88-challenged cells $(p<0.05)$. Meanwhile, we explored the distribution and abundance of zonula occludens-1 (ZO-1), one of the major tight-junctionrelated proteins located in the intestinal epithelium, by immuno-fluorescence analysis. We found that the ZO-1 staining in IPEC-J2 was diffuse due to E. coli K88 challenge, with less staining in the tight intercellular junction area, indicating disruption of the tight junction upon E. coli K88 infection. However, PNKL treatment attenuated the E. coli K88-induced disruption by improving the localization and abundance of the ZO-1 proteins in IPEC-J2 cells (Figure 6).

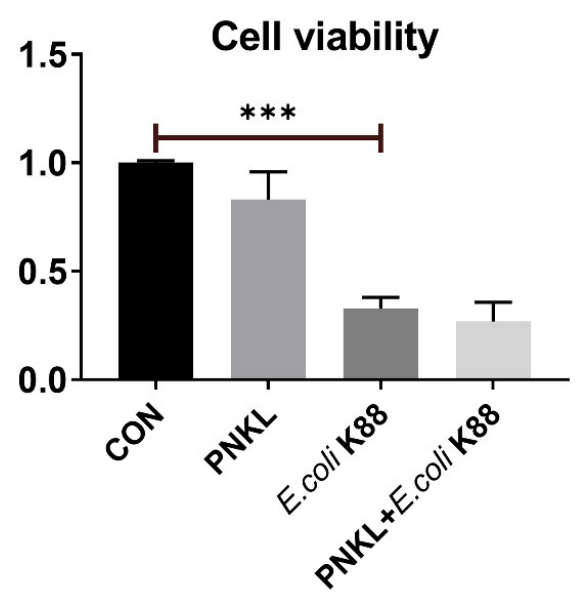

Figure 4. Influence of PNKL on E. coli K88-induced cell viability in IPEC-J2 cells. IPEC-J2 was determined by incubation with CCK8 for $1 \mathrm{~h}$ after different treatments. ${ }^{* * *}$ Means significant difference compared with blank control group $(p<0.001)$.
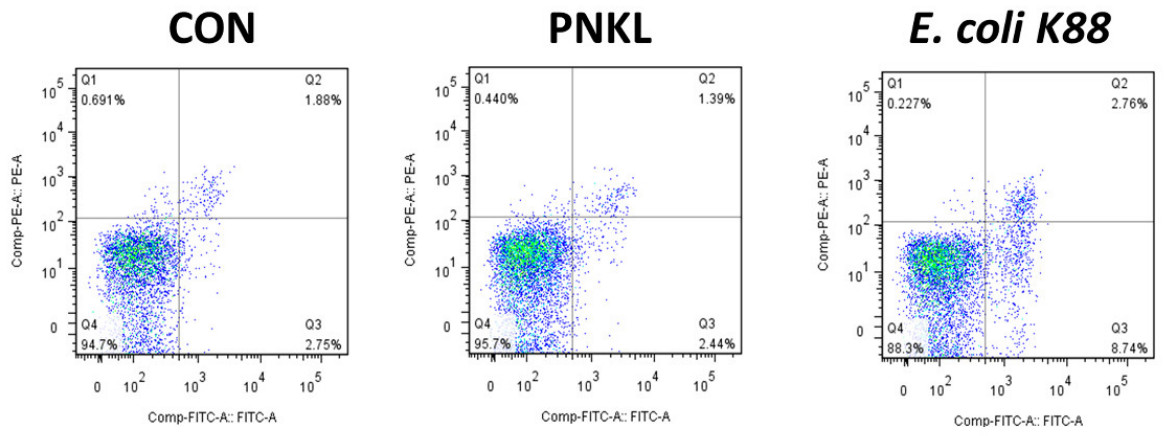

PNKL+E. coli K88
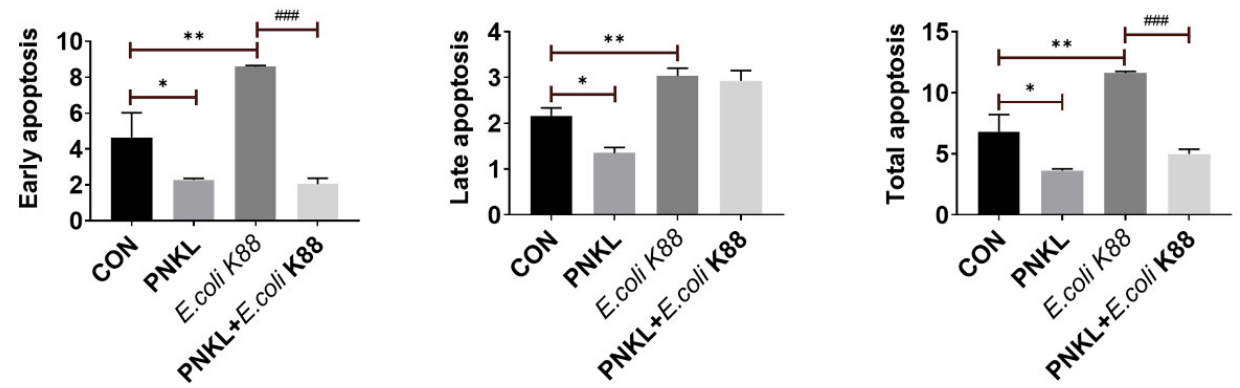

Figure 5. Influence of PNKL on E. coli K88-induced apoptosis in IPEC-J2 cells. Cell distribution analysis of apoptosis of IPEC-J2 cells treated with PNKL, E. coli K88, an PNKL plus E. coli K88. In each diagram, Q1 represents the percentage of non-viable, necrotic cells, Q2 represents the percentage of late apoptotic IPEC-J2 cells, Q3 represents the percentages of early apoptotic IPEC-J2 cells and Q4 represents the percentage of live IPEC-J2 cells. The statistical analysis of cell distribution data among samples, total apoptotic cells included Q2 with Q3. * Means significant difference compared with blank control group $(p<0.05),{ }^{* *}$ Means significant difference compared with blank control group $(p<0.01)$, \#\#\# Means significant difference compared with E. coli K88 control group $(p<0.001)$. 


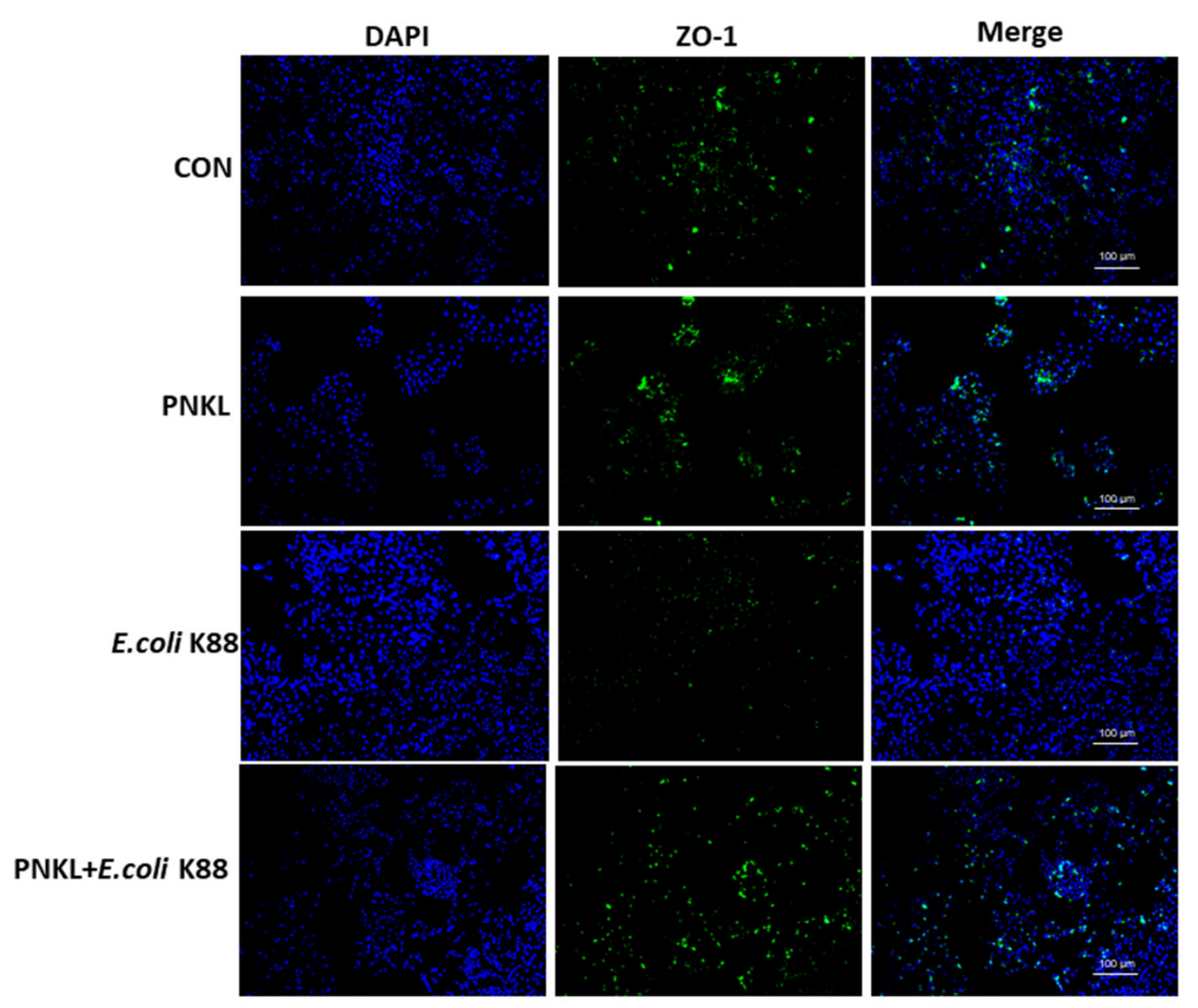

Figure 6. Effect of PNKL on distribution and abundance of ZO1 proteins. Representative immunofluorescent images for detection of ZO-1 (green) and DAPI (blue). Scale bar $=100 \mu \mathrm{m}$.

2.6. Effect of PNKL on Expressions of Genes Involved in Inflammatory Response and Cell Apoptosis

In this study, E. coli K88 challenge significantly elevated the expression levels of inflammatory cytokines such as the IL-6 and TNF- $\alpha$ in the IPEC-J2 cells (Figure 7A). Moreover, E. coli $\mathrm{K} 88$ can induce the expression of NF- $\mathrm{KB}$, and Toll-like receptor 4 (TLR4), the key proteins of the inflammatory signaling pathway, in which the expression of TLR4 is significantly increased (Figure 7B). However, PNKL treatment down-regulated their expression levels in the E. coli K88-challenged cells $(p<0.05)$. Moreover, PNKL treatment significantly down-regulated the expression level of caspase 3 and caspase 9 in the E. coli K88-challenged cells (Figure 7C) $(p<0.05)$. 
A
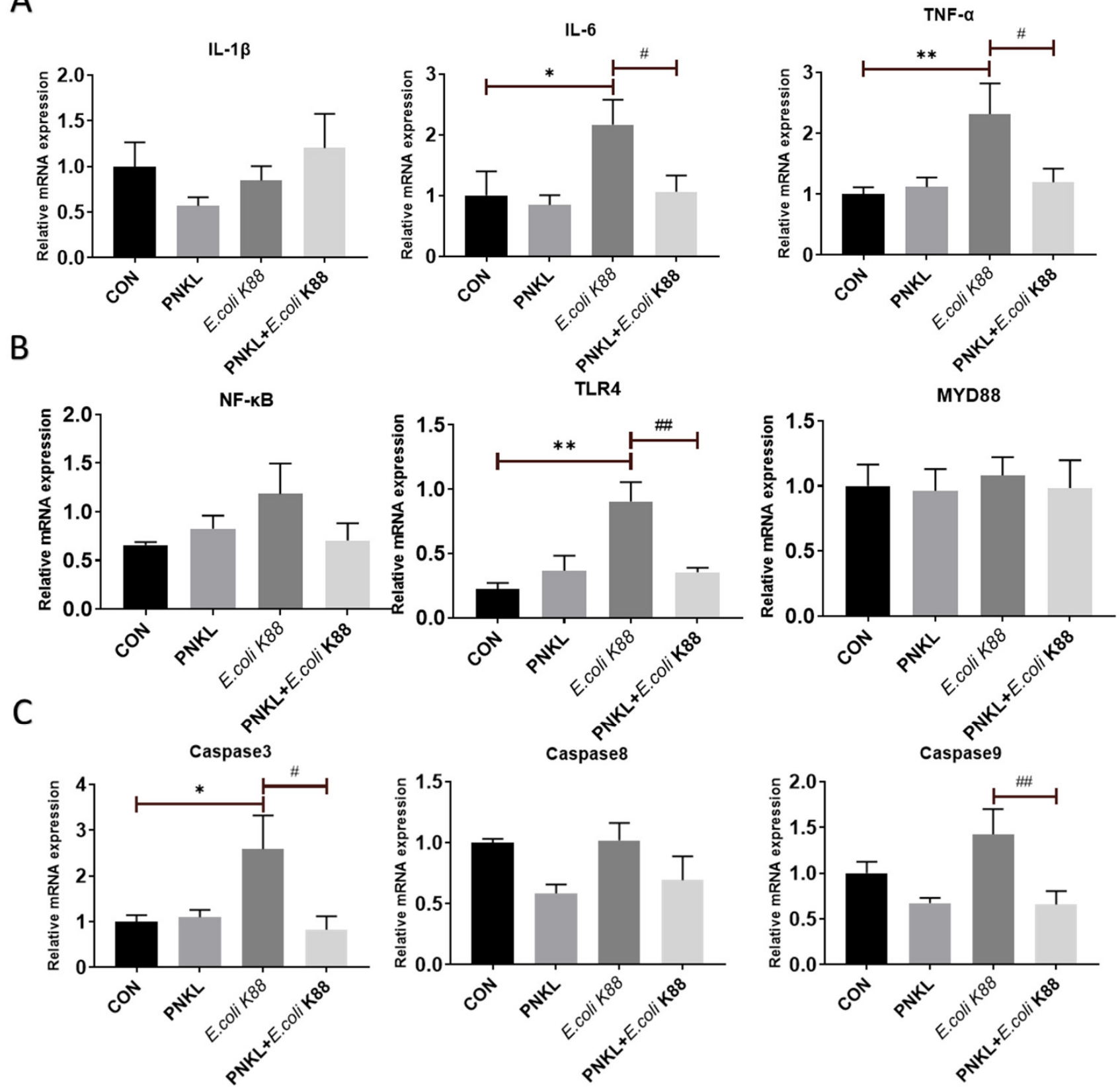

Figure 7. Influence of PNKL on E. coli K88-induced inflammatory responses in IPEC-J2 cells. Total RNA was extracted from IPEC-J2 cells and the expression of related genes were measured by real-time fluorescence PCR. The target gene mRNA expression level was calculated using the $2^{-\Delta \Delta C t}$ method. (A) Gene expression of the NF- $k B$ signaling pathway key factors. (B) Gene expression of the apoptotic factor. (C) Gene expression of the proinflammatory cytokine. ${ }^{*}$ Means significant difference compared with blank control group $(p<0.05)$, ${ }^{* *}$ Means significant difference compared with blank control group $(p<0.01)$, \# Means significant difference compared with E. coli K88 control group $(p<0.05)$, \#\# Means significant difference compared with E. coli K88 control group $(p<0.01)$. IL-1 $\beta$, interleukin 1 beta; IL-6, interleukin 6; TNF- $\alpha$, tumor necrosis factor alpha.

\section{Discussion}

Antibiotic resistance is an imminent threat to the effective treatment of bacterial infections, and there is an urgent need for alternative antibiotic strategies [27]. The development of new therapeutic agents to combat bacterial infections should be prioritized [28]. The production cost of peptides is an important factor hampering the development of AMPs. The production of AMPs by recombinant expression methods using microorganisms re- 
sistant to the peptide produced is one economically viable and promising alternative [29]. NK-lysin is a cationic antibacterial that was originally isolated from porcine intestinal tissue based on its antibacterial activity [30,31]. Currently, the NK-lysin has attracted considerable research interest since it has been reported to show a broad-spectrum antimicrobial activity and participate in the regulation of immune functions [20]. More than 12 kinds of porcine antimicrobial peptides have been found, including porcine thrombin, $\beta$-defensin-2, cecropin P1, and NK-lysin, which have broad-spectrum bactericidal effect on many microorganisms [32,33]. Among them, NK-lysin can directly combine the lipid part of lipopolysaccharide, resist various bacteria and fungi, such as E. coli, Bacillus megaterium, Acinetobacter acetate, and even dissolve some tumor cells [18]. In the present study, the PNKL was obtained by using heterologous expression, and the recombinant PNKL was purified and fully characterized.

The recombinant PNKL was estimated by SDS-PAGE to be $33 \mathrm{kDa}$. It is well known that culture conditions such as induction time and temperature can affect protein expression in the heterogenous expression system [34]. We obtained the highest yield of PNKL after inducing E. coli with IPTG for $6 \mathrm{~h}$. This is different from previous studies on the time when NK-lysin reaches its maximum expression [34]. The difference may result from the use of different bacteria strains. Interestingly, antimicrobial activity assays showed that PNKL has significant antimicrobial activity against both the Gram-positive bacteria (S. aureus and B. subtilis) and Gram-negative bacteria (E. coli K88 and S. typhimurium). The MIC for PNKL against $E$. coli $\mathrm{K} 88$ was $4 \mu \mathrm{g} / \mathrm{mL}$. PNKL also showed antibacterial activity against $S$. aureus (with a MIC of $2 \mu \mathrm{g} / \mathrm{mL}$ ), which is lower than NK-lysin obtained in the previous study [35]. These results are also consistent with a previous report on the PNKL, and both results indicated that the PNKL as well as its derivative had a broad-spectrum of antibacterial activities [24,36,37]. Importantly, hemolytic assays showed that PNKL had no detrimental impact on cell viability, similar to previous studies. This indicates that it is safe for human use and may be tentatively used as a substitute for conventionally used antibiotics [34].

In addition to its antibacterial activity, previous study suggests that PNKL is involved in the body's immune regulation [38]. For instance, chicken NK-lysin, fish NK-lysin, and salmo salar cathelicidin 1 were found to have both the anti-inflammatory and immunoregulatory functions [39-43]. Therefore, we further investigated the influence of PNKL on the inflammatory response of intestinal epithelial cells exposed to E. coli K88. We found that $E$. coli K88 challenge significantly decreased the cell viability and elevated the apoptosis rate in the IPEC-J2 cells. Our results are similar to those of previous studies in that microbial infection or stress can increase the apoptosis of intestinal epithelial cells [44]. Interestingly, PNKL significantly decreased the apoptosis in the E. coli K88-challenged cell. This is probably due to the down-regulation of several critical inflammatory cytokines such as the IL- $1 \beta$ and TNF- $\alpha$. Inflammatory cytokines, including IL-6, IL- $1 \beta$, and TNF- $\alpha$, are cytokines involved in inflammation, which could be released quickly under pathological conditions, leading to changes in systemic metabolism and disruption of the tissues such as the muscle and intestinal mucosa [45-47].

Tight junctions are composed of occludin, claudins, and zonula occludes (Zo)-1, -2, -3, which control the cell bypass permeability of endothelial cells and epithelial cells and provide barrier functions, such as inhibiting bacterial invasion [48]. However, various enteric pathogens can cause intestinal epithelial permeability defects by altering the distribution of tight junction proteins $[49,50]$. Previous studies indicated that $E$. coli infection elevated the mRNA and protein levels of tight junction proteins ZO-1 and occludin [51,52]. PNKL treatment attenuated the E. coli K88-induced mucosa lesion. In our study, the ZO-1 staining in the IPEC-J2 cells was diffuse with little staining at the intercellular tight junction region in the E. coli K88-challenged IPEC-J2 cells, indicating disruption of the TJs upon E. coli K88 infection. However, PNKL treatment attenuated the ETEC-induced TJs disruption by improving the localization and abundance of the $\mathrm{ZO}-1$ proteins. As the bacterial endotoxins (i.e., lipopolysaccharide) and inflammatory cytokines (i.e., TNF- $\alpha$ ) are detrimental to intestinal epithelial cells, they induce mucosal damage [53,54]. Therefore, we speculate 
that PNKL may improve mucosal morphology and tight junction due to its antibacterial and anti-inflammatory activities.

In order to further understand the mechanism of PNKL regulating intestinal barrier function, we explored the expression level of some critical molecules involved in inflammatory response and apoptosis regulation. Enteropathogenic bacteria (ETEC) adhere to the intestinal epithelium and cause severe diarrhea and intestinal inflammation through lipopolysaccharide (LPS), the main component of the cell wall [55]. LPS cannot directly destroy the integrity of cell structure and activate the signal pathway of apoptosis, but it can bind to TLR4, activate NF- $\mathrm{KB}$, signal pathway, and produce the inflammatory factor (i.e., TNF- $\alpha$ ) [56]. In the present study, an E. coli K88 challenge significantly elevated the expression level of TLR4 in the IPEC-J2 cells. Elevated TLR4 expression activates the NF- $\mathrm{KB}$ signaling pathway to release inflammatory cytokines. Many cationic peptides inhibit the proinflammatory response by reducing the proinflammatory mediators (mainly TNF- $\alpha$ ) $[57,58]$. Previous studies have found that Chicken NK-lysin derived peptide cNK2 can be used as an immunomodulator to regulate TLR agonist-induced inflammatory response [59]. In this study, E. coli K88 challenge significantly elevated IL- 6 and TNF- $\alpha$ expression levels in the IPEC-J2 cells. However, PNKL treatment resulted in significant down-regulation of the two critical inflammatory cytokines. Therefore, we speculate that PNKL may inhibit the NF- $\mathrm{kB}$ signaling pathway by inhibiting the expression of TLR4, resulting in decreased secretion of inflammatory cytokine. The specific mechanism needs to be further studied.

Caspases are an evolutionarily conserved family of cysteine proteases, mainly involved in cell death and inflammation [60]. The family of caspases can be functionally subdivided into initiators (caspases 8, 9, 10) and effectors (caspases 3, 6, 7) [61]. Among these executioners, caspase 3 is a cysteine-aspartic acid protease that cleaves cellular targets and executes cell death [62]. In this study, an E. coli K88 challenge significantly elevated the expression levels of caspase 3 in the IPEC-J2 cells, which was consistent with previous study on piglets [63]. However, PNKL can down-regulate the expression levels of caspase 3 and caspase 9 . This is probably due to the down-regulation of inflammatory cytokines (i.e., IL-6 and TNF- $\alpha$ ) since they were reported to induce apoptosis via activation of the caspase system $[64,65]$.

The PNKL shows a broad-spectrum of antimicrobial activities against both the Gramnegative and Gram-positive bacteria. However, it shows only a little light hemolytic activity and cytotoxicity. Moreover, PNKL increases the cell viability and attenuates the inflammatory response and injury in intestinal epithelial cells exposured to E. coli K88, which was associated with decreased cell apoptosis and down-regulation of inflammatory cytokines. The anti-bacterial and anti-inflammatory properties of PNKL may allow it to be a potential substitute for conventionally used antibiotics or drugs. However, there are still some unclear mechanisms, which need further exploration.

\section{Materials and Methods}

\subsection{Strains and Vectors}

The E. coli DH5 $\alpha$ and E. coli Rosetta (DE3) strains were purchased from TIANGEN (Beijing, China). E. coli K88 was kindly provided by Professor Lianqiang Che, Institute of Animal Nutrition, Sichuan Agricultural University. Salmonella typhimurium ATCC14028 (S. typhimurium), Staphylococcus aureus CICC23656 (S. aureus), and Bacillus subtilis (B. subtilis) were kindly provided by Professor Qigui Yan, College of Animal Science and Technology, Sichuan Agricultural University. The pET32a (+) was purchased from Invitrogen.

\subsection{Plasmid Construction}

PNKL gene was obtained by complete gene synthesis (Beijing Cycle-Tech Biotechnology Co., Ltd., Beijing, China). The company provides a cloned strain of DH5 $\alpha$-PMD19PNKL containing the target gene porcine NK-lysin (PNKL). Sequencing identification was. Performed at ShengGong Biological Engineering Co., Ltd. Sequencing results were com- 
pared by software DNAMAN. The plasmid PMD19-PNKL was extracted by using Plasmid Mini Kit I (Omega, Norcross, GA, USA) according to the manufacturer's recommendations. The plasmid pMD19-PNKL and expression vector pET32a (+) were double-digested with EcoRI and NotI Enzymes (Takara, Otsu, Japan) at $37^{\circ} \mathrm{C}$ for $4 \mathrm{~h}$. After purification by agarose gel electrophoresis, the isolated DNA fragments were ligated by T4 DNA ligase (Takara, Otsu, Japan). Then, the ligated product was transformed into E. coli $\mathrm{DH} 5 \alpha$ cells using the heat shock method and plated on LB agar containing kanamycin $(50 \mu \mathrm{g} / \mathrm{mL})$. The positive colonies were randomly picked, then confirmed by restriction enzyme digestion and sequenced by Sangon Biotech (Shanghai, China).

\subsection{Inducible Expression of PNKL}

For expression, plasmids pET32a (+)-PNKL gene were transformed into E. coli Rosetta (DE3) cells using heat shock method. Positive bacterial colonies were then confirmed as the methods of construction of the expression vector. The selected positive bacterial were incubated. Once $\mathrm{OD}_{600}$ reached $0.8,1.0 \mathrm{mM}$ isopropyl $\beta$-d-1-thiogalactoside (IPTG) was added to induce protein expression. After incubation for $6 \mathrm{~h}$ at $28^{\circ} \mathrm{C}$, bacterial cells were harvested by centrifugation at $8000 \times g$ for $10 \mathrm{~min}$ at $4{ }^{\circ} \mathrm{C}$ and lysis by lysis buffer $(500 \mathrm{mM}$ $\mathrm{NaCl}, 20 \mathrm{mM}$ Tris, $0.1 \%$ Triton X-100, $1 \mathrm{mM}$ PMSF, Lysozyme $0.2 \mathrm{mg} / \mathrm{mL}, 10 \mathrm{U} / \mathrm{mL}$ DNase (pH 7.5)) for $30 \mathrm{~min}$ at $4{ }^{\circ} \mathrm{C}$. Schizolytic cells were then sonicated (4 s pulse and $8 \mathrm{~s}$ interval; 30 cycles; Sonics-Vibra cell). They were then centrifuged at $15,000 \times g$ for $30 \mathrm{~min}$ at $4{ }^{\circ} \mathrm{C}$ and the supernatant was run on $12 \%$ SDS-PAGE or for affinity purification.

\subsection{Affinity Purification}

The supernatant obtained above was filtered by $0.22 \mu \mathrm{m}$ filter, and then applied to Ni $2^{+}$-IDA column (Sangon Biotech, Shanghai, China) and purified according to the manufacturer's specifications. Briefly, 10 resin volumes of Binding Buffer $\left(50 \mathrm{mM} \mathrm{NaH}_{2} \mathrm{PO}_{4}\right.$, $300 \mathrm{mM} \mathrm{NaCl}, \mathrm{pH} 8.0$ ) was added to wash way the impure protein, then 5 resin volumes of Elution Buffer ( $50 \mathrm{mM} \mathrm{NaH}{ }_{2} \mathrm{PO}_{4}, 300 \mathrm{mM} \mathrm{NaCl}, 150 \mathrm{mM}$ Imidazole, $\mathrm{pH}$ 8.0) was added to elute the PNKL from the column. The protein concentration was quantified with the BCA assay (Beyotime, Shanghai, China). The purified PNKL was run on $12 \%$ SDS-PAGE. The rest was stored at $-80^{\circ} \mathrm{C}$ to analyze antimicrobial activities.

\subsection{Antimicrobial Activity Assays}

The minimal inhibitory concentration (MIC) of purified PNKL was measured by the microtiter broth dilution method [66]. E. coli $\mathrm{DH} 5 \alpha$, pathogenic E. coli $\mathrm{K} 88+$, S. typhimurium, S. aureus, and B. subtilis were grown to $0.4 \mathrm{OD}_{600} \mathrm{~nm}$ at $37^{\circ} \mathrm{C}$ in $\mathrm{LB}$, Streptococcus was grown to $0.4 \mathrm{OD}_{600} \mathrm{~nm}$ at $37^{\circ} \mathrm{C}$ in THY (Todd-Hewitt + yeast extract). The target cell culture was diluted to $1 \times 10^{5} \mathrm{CFUs} / \mathrm{mL}$ with the same media respectively. A total of $100 \mu \mathrm{L}$ of PNKL and $100 \mu \mathrm{L}$ of cell suspension were added into each well. The activity of PNKL was tested over a concentration range of $256,128,64,32,16,8,4,2$, and $1 \mu \mathrm{g} / \mathrm{mL}$, and all assays were tested in triplicate. Bacterial plates were incubated at $37^{\circ} \mathrm{C}$ for $16 \mathrm{~h}$, and the absorption of cell culture was recorded at $600 \mathrm{~nm}$. MIC was defined as the lowest concentration of peptide at which there was no change in optical density.

\subsection{Hemolytic Activity Assay}

The hemolytic activity of PNKL was measured spectrophotometrically using a hemoglobin release assay [67]. Fresh pig blood was collected in a heparinized-tube and centrifuged at $1500 \mathrm{rpm}$ for $10 \mathrm{~min}$. This study was approved by the Animal Welfare Committee of Sichuan Agricultural University (No. 20180718). The pellet was gently washed three times with cold PBS ( $\mathrm{pH} 7.2$ ), and resuspended in cold PBS (pH 7.2), then the erythrocytes concentration was adjusted to $4 \%$. A $200 \mu \mathrm{L}$ erythrocyte suspension was added to a 96-well microtiter plate. Different concentrations of NK-lysin solution were added to each well and incubated for $60 \mathrm{~min}$ at $37^{\circ} \mathrm{C}$. Triton-X $100(0.1 \%)$ and PBS were used as positive and negative controls, respectively. The release of hemoglobin of the supernatant 
was measured after centrifugation (1000 rpm for $5 \mathrm{~min}$ ) by UV-1100 spectrophotometer (Shanghai, China) at $414 \mathrm{~nm}$. No hemolysis and 100\% hemolysis were determined in PBS and Triton X-100, respectively.

\subsection{Cell Culture}

Intestinal porcine epithelial cells (IPEC-J2) were cultured in a $75 \mathrm{~cm}^{2}$ cell culture flask in DMEM-F12 with 10\% FBS, $100 \mathrm{U} / \mathrm{mL}$ penicillin, and $100 \mu \mathrm{g} / \mathrm{mL}$ streptomycin. Next, $1 \times 10^{5}$ cells / well were seeded in 12-well plates and grown to $\sim 60 \%$ confluence at $37{ }^{\circ} \mathrm{C}$ in a $\mathrm{CO}_{2}$ incubator $(5 \% \mathrm{v} / \mathrm{v})$, then incubated with antimicrobial peptides PNKL for $24 \mathrm{~h}$ (PNKL, PNKL+E. coli K88). Cells were challenged with $1 \times 10^{6} \mathrm{CFU} /$ well E. coli K88 for $1 \mathrm{~h}$ (PNKL+E. coli K88, E. coli K88), and control cells were cultured in a culture medium of $2 \%$ serum (without any antibiotics) without any treatment. Total cellular RNA was collected using RNAiso Plus (Takara, Dalian, China).

\subsection{Cytotoxicity Assay}

The cytotoxicity of PNKL was measured according to a previous study [68]. Briefly, IPEC-J2 cells were cultured in DMEM-F12 with 10\% FBS, $100 \mathrm{U} / \mathrm{mL}$ penicillin, and $100 \mu \mathrm{g} / \mathrm{mL}$ streptomycin for $48 \mathrm{~h}$ and then resuspended to $10^{5}$ cells $/ \mathrm{mL}$ in FBS free DMEM-F12 media. A volume of $100 \mu \mathrm{L}$ of cells was aliquoted into sterile flat-bottomed 96-well plates (Corning, New York, NY, USA). The PNKL was added to the cells and incubated at $37^{\circ} \mathrm{C} / 5 \% \mathrm{CO}_{2}$ for $24 \mathrm{~h}$ (PNKL, PNKL+E. coli K88). Then cells were challenged with $1 \times 10^{6} \mathrm{CFU} /$ well E. coli K88 for $1 \mathrm{~h}(\mathrm{PNKL}+$ E. coli K88, E. coli K88), control cells were cultured in complete medium without any treatment. Cell viability was evaluated with the CCK-8 assay (Beyotime, Shanghai, China) according to the manufacturer's instructions.

\subsection{Assessment of Apoptosis by Flow Cytometry}

The proportion of apoptotic cells in IPEC-J2 cells was determined by flow cytometry (CytoFlex, Beckman Coulter, Inc., Brea, CA, USA) using PE Annexin V Apoptosis Detection Kit I (Becton, Dickinson and Company, BD Biosciences, San Jose, CA, USA). When IPEC-J2 cells were grown to $\sim 60 \%$ confluence at $37{ }^{\circ} \mathrm{C}$ in a $\mathrm{CO}_{2}$ incubator $(5 \% v / v)$, they were incubated with PNKL for $24 \mathrm{~h}$ (PNKL, PNKL + E. coli K88). Cells were challenged with $1 \times 10^{6} \mathrm{CFU} /$ well E. coli K88 for $2.5 \mathrm{~h}(\mathrm{PNKL}+E$. coli K88, E. coli K88) before sample collection, and control cells were cultured in a culture medium without any treatment. Treated cells were harvested and labeled with an anti-Annexin V-FITC Apoptosis Detection Kit (BD Biosciences, San Jose, CA, USA). Floating cells were collected, then attached cells were washed with $0.01 \mathrm{M}$ PBS and digested with trypsin for $2 \mathrm{~min}$. Finally, the digested cells and floating cells were added together to centrifugate at $350 \times g$ for $10 \mathrm{~min}$, then the cells were stained with $2 \mu \mathrm{L}$ of Annexin-V FITC fluorescent dye at $4{ }^{\circ} \mathrm{C}$ in the dark. After $10 \mathrm{~min}, 2 \mu \mathrm{L}$ of PI staining was added for $5 \mathrm{~min}$ at $4{ }^{\circ} \mathrm{C}$ in the dark. Finally, detection of apoptotic cells was completed within $1 \mathrm{~h}$ after the addition of $400 \mu \mathrm{L}$ Annexin $\mathrm{V}$ binding buffer $(1 \times)$.

\subsection{RNA Extraction and RT-PCR}

IPEC-J2 cells were harvested and the total RNA was extracted using RNAiso Plus (Takara, Dalian, China) according to the manufacturer's instructions. The quantity and quality of the isolated RNA were determined by absorbance at 260 and $280 \mathrm{~nm}$ [69]. cDNA was synthesized using a Reverse Transcriptase kit (Takara, Dalian, China). Briefly, quantitative PCR was performed by QuanStudio 6 Flex Real-Time PCR detection system (Applied Biosystems, Foster City, CA, USA) with a total of $10 \mu \mathrm{L}$ of assay solution containing $5 \mu \mathrm{L}$ SYBR Green mix (Takara), $0.2 \mu \mathrm{L}$ Rox, $3 \mu \mathrm{L}$ deionized $\mathrm{H}_{2} \mathrm{O}, 1 \mu \mathrm{L}$ cDNA template, and $0.4 \mu \mathrm{L}$ each of forward and reverse primers (Qingke, Beijing, China). The relative gene expressions compared with the housekeeping gene $\beta$-actin were calculated by $2^{-\mathrm{CT}}$ [70]. 


\subsection{Immunofluorescence}

IPEC-J2 cells were cultured in DMEM-F12 with 10\% FBS, $100 \mathrm{U} / \mathrm{mL}$ penicillin, and $100 \mu \mathrm{g} / \mathrm{mL}$ streptomycin for $48 \mathrm{~h}$ and then resuspended to $10^{5}$ cells $/ \mathrm{mL}$ in FBS free DMEM-F12 media. A volume of $1 \mathrm{~mL}$ of cells was aliquoted into sterile flat-bottomed 12-well plates (Corning, New York, NY, USA). The PNKL was added to the cells and incubated at $37^{\circ} \mathrm{C} / 5 \% \mathrm{CO}_{2}$ for $24 \mathrm{~h}$ (PNKL, PNKL+E. coli K88). Cells were challenged with $1 \times 10^{6} \mathrm{CFU} /$ well E. coli K88 for $1 \mathrm{~h}$ (PNKL+E. coli K88, E. coli K88), and control cells were cultured in complete medium without any treatment. We added $300 \mu \mathrm{L}$ of fixative solution (4\% paraformaldehyde) into each well and left them to stand for $15 \mathrm{~min}$ at room temperature. Each well was washed three times with PBS (pH 7.4) for 2 min each time, and then samples were incubated overnight with the primary antibody at $4{ }^{\circ} \mathrm{C}$ and kept in the dark (rabbit anti-ZO-1; Novus). The samples were washed three times with PBS (pH 7.4) for $2 \mathrm{~min}$ each time and incubated for $2 \mathrm{~h}$ at room temperature with the appropriate secondary antibody (Alexa Fluor 488 conjugated goat anti-rabbit immunoglobulin (CST)). Samples with the biotinylated secondary antibody were incubated with Avidin Alexa Fluor 488 (CST) for visualization of the secondary antibody. Samples were washed, and nuclei were counterstained with DAPI (Sigma-Aldrich, St. Louis, MO, USA). Samples were imaged using a leica inverted microscope (DMI4000B).

\subsection{Statistics Analysis}

All statistical analysis was performed using SPSS 21.0 software. Data were expressed as the mean \pm standard error of the mean (SEM). Statistical analysis of treatment of IPEC-J2 and cytotoxicity were carried out using two-way ANOVA followed by Duncan's multiple comparisons test. Image production was performed using GraphPad Prism software (Version 7. GraphPad Software Inc., San Diego, CA, USA).

Supplementary Materials: The following are available online, Figure S1: Strategy of cloning of PNKL gene. The CDS sequence without signal peptide of PNKL was cloned, EcoR I and Not I was insert in $5^{\prime}$ and $3^{\prime}$ respectively, Figure S2: Results from agarose gel electrophoresis (EcoR I/Not I digestion map). (A) Digestion of the recombinant expression vectors. Lane M1 DNA marker (DL 10,000), Lanes 1 PNKL (without digestion). Lanes 2 PNKL (digestion with EcoR I and Not I) Lane M2 DNA marker (DL 2000). (B) RT-PCR of PNKL. Lane M DNA marker (DL 4000), Lanes 1-2 PNKL (production of five tubes of reaction solution).

Author Contributions: Q.L. performed animal trial and prepared the manuscript. Q.L. and Q.F. conducted the expression of PNKL protein and chemical analysis. J.H. contributed to experimental design and revised the manuscript. D.C., B.Y. and Y.L. conceived this study and help to manuscript revision. Z.H., J.Y., P.Z., X.M., J.L. and H.Y. contributed to the sample collection and biochemical analysis. All authors have read and agreed to the published version of the manuscript.

Funding: This work was supported by the Development program of Sichuan Province (2020YFN0147) and the National Natural Science Foundation of China (31972599), and the Youth Innovation teams of animal Feed Biotechnology of Sichuan Province (2016TD0028).

Institutional Review Board Statement: This study was approved by the Animal Welfare Committee of Sichuan Agricultural University (No. 20180718).

Informed Consent Statement: Not applicable.

Data Availability Statement: The datasets during and/or analyzed during the current study are available from the corresponding author on reasonable request.

Acknowledgments: We thank Yaqiang Dai and Xiang Li for their help in the animal experiments. We also thank Huifen Wang and Quyuan Wang for purchasing consumables and reagents.

Conflicts of Interest: All authors have declared that there are no financial conflict of interest with regard to this work.

Sample Availability: Samples of the compounds are not available from the authors. 


\section{Abbreviation}

MIC minimal inhibitory concentration

\section{References}

1. Bosák, J.; Hrala, M.; Pirková, V.; Micenková, L.; Č́́žek, A.; Smola, J.; Kučerová, D.; Vacková, Z.; Budinská, E.; Koláčková, I.; et al. Porcine pathogenic Escherichia coli strains differ from human fecal strains in occurrence of bacteriocin types. Vet. Microbiol. 2019, 232, 121-127. [CrossRef]

2. $\quad$ Chen, C.; Wang, L.-P.; Yu, J.-X.; Chen, X.; Wang, R.-N.; Yang, X.-Z.; Zheng, S.-F.; Yu, F.; Zhang, Z.-K.; Liu, S.-J.; et al. Prevalence of Enteropathogens in Outpatients with Acute Diarrhea from Urban and Rural Areas, Southeast China, 2010-2014. Am. J. Trop. Med. Hyg. 2019, 101, 310-318. [CrossRef]

3. Al-Alo, K.Z.K.; Brujeni, G.N.; Lotfollahzadeh, S.; Moosakhani, F.; Gharabaghi, A. Correlation between neonatal calf diarrhea and the level of maternally derived antibodies. Iran. J. Vet. Res. 2018, 19, 3-8. [CrossRef]

4. Gao, P.; Mao, D.; Luo, Y.; Wang, L.; Xu, B.; Xu, L. Occurrence of sulfonamide and tetracycline-resistant bacteria and resistance genes in aquaculture environment. Water Res. 2012, 46, 2355-2364. [CrossRef] [PubMed]

5. Lieverse, R.I.Y.; Marcus, D.; Van Der Wiel, A.M.; Van Limbergen, E.J.; Theys, J.; Yaromina, A.; Lambin, P.; Dubois, L.J. Human fibronectin extra domain B as a biomarker for targeted therapy in cancer. Mol. Oncol. 2020, 14, 1555-1568. [CrossRef]

6. Bessone, F.A.; Bessone, G.; Marini, S.; Conde, M.B.; Alustiza, F.E.; Zielinski, G. Presence and characterization of Escherichia coli virulence genes isolated from diseased pigs in the central region of Argentina. Vet. World 2017, 10, 939-945. [CrossRef]

7. Zasloff, M. Antimicrobial peptides of multicellular organisms. Nature 2002, 415, 389-395. [CrossRef] [PubMed]

8. Su, G.; Tang, F.; Chen, D.; Yu, B.; Huang, Z.; Luo, Y.; Mao, X.; Zheng, P.; Yu, J.; Luo, J.; et al. Expression, Purification and Characterization of a Novel Antimicrobial Peptide: Gloverin A2 from Bombyx mori. Int. J. Pept. Res. Ther. 2019, 25, 827-833. [CrossRef]

9. Jenssen, H.; Hamill, P.; Hancock, R. Peptide Antimicrobial Agents. Clin. Microbiol. Rev. 2006, 19, 491-511. [CrossRef] [PubMed]

10. Semeraro, E.F.; Mandl, J.; Marx, L.; Narayanan, T.; Prévost, S.; Bergler, H.; Lohner, K.; Pabst, G. Antimicrobial Peptides Impair Bacteria Cell Structures within Seconds. Biophys. J. 2020, 118, 234A. [CrossRef]

11. Hammami, R.; Ben Hamida, J.; Vergoten, G.; Lacroix, J.-M.; Slomianny, M.-C.; Mohamed, N.; Fliss, I. A new antimicrobial peptide isolated from Oudneya africana seeds. Microbiol. Immunol. 2009, 53, 658-666. [CrossRef]

12. Martínez, M.; Polizzotto, A.; Flores, N.; Semorile, L.; Maffía, P.C. Antibacterial, anti-biofilm and in vivo activities of the antimicrobial peptides P5 and P6.2. Microb. Pathog. 2020, 139, 103886. [CrossRef]

13. Brogden, K.A. Antimicrobial peptides: Pore formers or metabolic inhibitors in bacteria? Nat. Rev. Microbiol. 2005, 3, 238-250. [CrossRef]

14. Deng, Z.; Xu, C. Role of the neuroendocrine antimicrobial peptide catestatin in innate immunity and pain. Acta Biochim. Biophys. Sin. 2017, 49, 967-972. [CrossRef]

15. Grassi, L.; Maisetta, G.; Maccari, G.; Esin, S.; Batoni, G. Analogs of the Frog-skin Antimicrobial Peptide Temporin 1Tb Exhibit a Wider Spectrum of Activity and a Stronger Antibiofilm Potential as Compared to the Parental Peptide. Front. Chem. 2017, 5, 24. [CrossRef] [PubMed]

16. Singh, M.; Mukhopadhyay, K. Alpha-Melanocyte Stimulating Hormone: An Emerging Anti-Inflammatory Antimicrobial Peptide. BioMed Res. Int. 2014, 2014, 874610. [CrossRef] [PubMed]

17. Andersson, M.; Curstedt, T.; Jörnvall, H.; Johansson, J. An amphipathic helical motif common to tumourolytic polypeptide NK-lysin and pulmonary surfactant polypeptide SP-B. FEBS Lett. 1995, 362, 328-332. [CrossRef]

18. Hirono, I.; Kondo, H.; Koyama, T.; Arma, N.R.; Hwang, J.Y.; Nozaki, R.; Midorikawa, N.; Aoki, T. Characterization of Japanese flounder (Paralichthys olivaceus) NK-lysin, an antimicrobial peptide. Fish Shellfish Immunol. 2007, 22, 567-575. [CrossRef]

19. Andersson, M.; Gunne, H.; Agerberth, B.; Boman, A.; Bergman, T.; Sillard, R.; Jörnvall, H.; Mutt, V.; Olsson, B.; Wigzell, H. NK-lysin, a novel effector peptide of cytotoxic T and NK cells. Structure and cDNA cloning of the porcine form, induction by interleukin 2, antibacterial and antitumour activity. EMBO J. 1995, 14, 1615-1625. [CrossRef]

20. Hong, Y.H.; Lillehoj, H.S.; Siragusa, G.R.; Bannerman, D.D.; Lillehoj, E.P. Antimicrobial Activity of Chicken NK-Lysin against Eimeria Sporozoites. Avian Dis. 2008, 52, 302-305. [CrossRef]

21. Zhang, M.; Long, H.; Sun, L. A NK-lysin from Cynoglossus semilaevis enhances antimicrobial defense against bacterial and viral pathogens. Dev. Comp. Immunol. 2013, 40, 258-265. [CrossRef] [PubMed]

22. Yan, J.-X.; Wang, K.-R.; Chen, R.; Song, J.-J.; Zhang, B.-Z.; Dang, W.; Zhang, W.; Wang, R. Membrane active antitumor activity of NK-18, a mammalian NK-lysin-derived cationic antimicrobial peptide. Biochimie 2012, 94, 184-191. [CrossRef] [PubMed]

23. Banković, J.; Andrä, J.; Todorović, N.; Podolski-Renić, A.; Milošević, Z.; Miljković, Đ.; Krause, J.; Ruždijić, S.; Tanić, N.; Pešić, M. The elimination of P-glycoprotein over-expressing cancer cells by antimicrobial cationic peptide NK-2: The unique way of multi-drug resistance modulation. Exp. Cell Res. 2013, 319, 1013-1027. [CrossRef]

24. Lee, M.O.; Kim, E.-H.; Jang, H.-J.; Na Park, M.; Woo, H.-J.; Han, J.Y.; Womack, J.E. Effects of a single nucleotide polymorphism in the chicken NK-lysin gene on antimicrobial activity and cytotoxicity of cancer cells. Proc. Natl. Acad. Sci. USA 2012, 109, 12087-12092. [CrossRef] 
25. Fan, K.; Du, W.; Wang, Z.; Khan, A.; Li, H.; Jiang, J. Anti-Invasion and Antimetastatic Effects of Porcine Recombinant NK-lysin on SMMC-7721 Human Hepatocellular Carcinoma Cells. BioMed Res. Int. 2019, 2019, 5318729. [CrossRef] [PubMed]

26. Lin, Q.; Su, G.; Wu, A.; Chen, D.; Yu, B.; Huang, Z.; Luo, Y.; Mao, X.; Zheng, P.; Yu, J.; et al. Bombyx mori gloverin A2 alleviates enterotoxigenic Escherichia coli-induced inflammation and intestinal mucosa disruption. Antimicrob. Resist. Infect. Control 2019, 8, 189. [CrossRef]

27. Yusuf, E. Imminent threat of antibiotic resistance and the importance of diagnostic and antibiotic stewardship. Universa Med. 2017, 36, 157-159. [CrossRef]

28. Lewies, A.; Du Plessis, L.H.; Wentzel, J.F. Antimicrobial Peptides: The Achilles' Heel of Antibiotic Resistance? Probiotics Antimicrob. Proteins 2019, 11, 370-381. [CrossRef]

29. Giuliani, A.; Pirri, G.; Nicoletto, S. Antimicrobial peptides: An overview of a promising class of therapeutics. Cent. Eur. J. Biol. 2007, 2, 1-33. [CrossRef]

30. Lee, M.O.; Jang, H.-J.; Han, J.Y.; Womack, J.E. Chicken NK-lysin is an alpha-helical cationic peptide that exerts its antibacterial activity through damage of bacterial cell membranes. Poult. Sci. 2014, 93, 864-870. [CrossRef] [PubMed]

31. Andersson, M.; Gunne, H.; Agerberth, B.; Boman, A.; Bergman, T.; Olsson, B.; Dagerlind, Å.; Wigzell, H.; Boman, H.; Gudmundsson, G. NK-lysin, structure and function of a novel effector molecule of porcine T and NK cells. Vet. Immunol. Immunopathol. 1996, 54, 123-126. [CrossRef]

32. Lv, X.; Ma, Q.; Zhu, D.; Shao, C.; And, Y.L.; Shan, A. The C-terminal sequences of porcine thrombin are active as antimicrobial peptides. Chem. Biol. Drug Des. 2016, 88, 905-914. [CrossRef] [PubMed]

33. Xu, J.; Zhong, F.; Zhang, Y.; Zhang, J.; Huo, S.; Lin, H.; Wang, L.; Cui, D.; Li, X. Construction of Bacillus subtilis strain engineered for expression of porcine $\beta$-defensin-2/cecropin P1 fusion antimicrobial peptides and its growth-promoting effect and antimicrobial activity. Asian Australas. J. Anim. Sci. 2016, 30, 576-584. [CrossRef] [PubMed]

34. Fan, K.; Li, H.; Wang, Z.; Du, W.; Yin, W.; Sun, Y.; Jiang, J. Expression and purification of the recombinant porcine NK-lysin in Pichia pastoris and observation of anticancer activity in vitro. Prep. Biochem. Biotechnol. 2016, 46, 65-70. [CrossRef]

35. Zhou, Q.-J.; Wang, J.; Liu, M.; Qiao, Y.; Hong, W.-S.; Su, Y.-Q.; Han, K.-H.; Ke, Q.-Z.; Zheng, W.-Q. Identification, expression and antibacterial activities of an antimicrobial peptide NK-lysin from a marine fish Larimichthys crocea. Fish Shellfish Immunol. 2016, 55, 195-202. [CrossRef]

36. Hong, S.-M.; Kusakabe, T.; Lee, J.-M.; Tatsuke, T.; Kawaguchi, Y.; Kang, M.-W.; Kang, S.-W.; Kim, K.-A.; Nho, S.-K. Structure and Expression Analysis of the Cecropin-E Gene from the Silkworm, Bombyx mori. Biosci. Biotechnol. Biochem. 2008, 72, $1992-1998$. [CrossRef]

37. Lee, S.H.; Lillehoj, H.S.; Tuo, W.; Murphy, C.A.; Hong, Y.H.; Lillehoj, E.P. Parasiticidal activity of a novel synthetic peptide from the core $\alpha$-helical region of NK-lysin. Vet. Parasitol. 2013, 197, 113-121. [CrossRef] [PubMed]

38. Fischer, U.; Koppang, E.O.; Nakanishi, T. Teleost T and NK cell immunity. Fish Shellfish Immunol. 2013, 35, 197-206. [CrossRef] [PubMed]

39. Sarson, A.J.; Abdul-Careem, M.F.; Read, L.R.; Brisbin, J.T.; Sharif, S. Expression of Cytotoxicity-Associated Genes in Marek's Disease Virus-Infected Chickens. Viral Immunol. 2008, 21, 267-272. [CrossRef]

40. Rauf, A.; Khatri, M.; Murgia, M.V.; Saif, Y.M. Expression of perforin-granzyme pathway genes in the bursa of infectious bursal disease virus-infected chickens. Dev. Comp. Immunol. 2011, 35, 620-627. [CrossRef]

41. Kim, J.-K.; Lee, E.; Shin, S.; Jeong, K.-W.; Lee, J.-Y.; Bae, S.-Y.; Kim, S.-H.; Lee, J.; Kim, S.R.; Lee, D.G.; et al. Structure and Function of Papiliocin with Antimicrobial and Anti-inflammatory Activities Isolated from the Swallowtail Butterfly, Papilio xuthus. J. Biol. Chem. 2011, 286, 41296-41311. [CrossRef]

42. Valero, Y.; Chaves-Pozo, E.; Cuesta, A. NK-lysin is highly conserved in European sea bass and gilthead seabream but differentially modulated during the immune response. Fish Shellfish Immunol. 2020, 99, 435-441. [CrossRef]

43. Zou, T.; Zheng, C.; Zhang, Z.; Yu, L.; Fu, C. Neoadjuvant chemotherapy efficacy and prognostic factors in 187 cervical cancer patients with IB2 and IIA2 stage. J. Cent. South Univ. 2020, 45, 297-304. [CrossRef]

44. Wang, K.; Su, R.; Sun, X.; Jiang, J.; Ma, Q. Progress in applications of ${ }^{18}$ F-fluciclovine in diagnosis of prostate cancer. J. Cent. South Univ. 2020, 45, 187-192. [CrossRef]

45. Li, Y.; Shen, R.; Wen, G.; Ding, R.; Du, A.; Zhou, J.; Dong, Z.; Ren, X.; Yao, H.; Zhao, R.; et al. Effects of Ketamine on Levels of Inflammatory Cytokines IL-6, IL-1 $\beta$, and TNF- $\alpha$ in the Hippocampus of Mice Following Acute or Chronic Administration. Front. Pharmacol. 2017, 8, 139. [CrossRef]

46. McKay, D.M.; Baird, A.W. Cytokine regulation of epithelial permeability and ion transport. Gut 1999, 44, 283-289. [CrossRef] [PubMed]

47. Szczepankiewicz, D.; Skrzypski, M.; Pruszyńska-Oszmałek, E.; Kolodziejski, P.; Sassek, M.; Stefańska, B.; Nowak, K.W.; Szczepankiewicz, A. Interleukin 4 affects lipid metabolism and the expression of pro-inflammatory factors in mature rat adipocytes. Immunobiology 2018, 223, 677-683. [CrossRef] [PubMed]

48. Zihni, C.; Mills, C.; Matter, K.; Balda, M. Tight junctions: From simple barriers to multifunctional molecular gates. Nat. Rev. Mol. Cell Biol. 2016, 17, 564-580. [CrossRef] [PubMed]

49. Tong, L.-C.; Wang, Y.; Wang, Z.-B.; Liu, W.-Y.; Sun, S.; Li, L.; Su, D.-F.; Zhang, L.-C. Propionate Ameliorates Dextran Sodium Sulfate-Induced Colitis by Improving Intestinal Barrier Function and Reducing Inflammation and Oxidative Stress. Front. Pharmacol. 2016, 7, 253. [CrossRef] 
50. Taupin, D.; Podolsky, D.K. Trefoil factors: Initiators of mucosal healing. Nat. Rev. Mol. Cell Biol. 2003, 4, 721-732. [CrossRef] [PubMed]

51. Wang, L.; Yi, H.; Wang, Z.; Qiu, Y.; Wen, X.; Ma, X.; Yang, X.; Jiang, Z. 452 Effects of Lactobacillus reuteri LR1 on tight junction proteins expression in Ipec-1 cells during enterotoxigenic Escherichia coli K88 infection and its underlying mechanisms. J. Anim. Sci. 2017, 95, 222. [CrossRef]

52. Yang, G.-Y.; Zhu, Y.-H.; Zhang, W.; Zhou, D.; Zhai, C.-C.; Wang, J.-F. Influence of orally fed a select mixture of Bacillus probiotics on intestinal T-cell migration in weaned MUC4 resistant pigs following Escherichia coli challenge. Vet. Res. 2016, 47, 71. [CrossRef] [PubMed]

53. Wollersheim, B.M.; Van Stam, M.-A.; Bosch, R.J.; Pos, F.J.; Tillier, C.N.; Van Der Poel, H.G.; Aaronson, N.K. Unmet expectations in prostate cancer patients and their association with decision regret. J. Cancer Surviv. 2020, 14, 731-738. [CrossRef] [PubMed]

54. Wang, H.; Meng, X.-L.; Xu, J.-P.; Wang, J.; Wang, H.; Ma, C.-W. Production, purification, and characterization of the cecropin from Plutella xylostella, pxCECA1, using an intein-induced self-cleavable system in Escherichia coli. Appl. Microbiol. Biotechnol. 2012, 94, 1031-1039. [CrossRef] [PubMed]

55. Li, Y.; Wang, J.; Li, Y.; Wu, H.; Zhao, S.; Yu, Q. Protecting intestinal epithelial cells against deoxynivalenol and E. coli damage by recombinant porcine IL-22. Vet. Microbiol. 2019, 231, 154-159. [CrossRef] [PubMed]

56. Pace, E.; Ferraro, M.; Di Vincenzo, S.; Siena, L.; Gjomarkaj, M. Effects of ceftaroline on the innate immune and on the inflammatory responses of bronchial epithelial cells exposed to cigarette smoke. Toxicol. Lett. 2016, 258, 216-226. [CrossRef]

57. Scott, M.G.; Dullaghan, E.; Mookherjee, N.; Glavas, N.; Waldbrook, M.; Thompson, A.; Wang, A.; Lee, K.; Doria, S.; Hamill, P.; et al. An anti-infective peptide that selectively modulates the innate immune response. Nat. Biotechnol. 2007, 25, 465-472. [CrossRef]

58. Mookherjee, N.; Brown, K.; Bowdish, D.M.E.; Doria, S.; Falsafi, R.; Hokamp, K.; Roche, F.M.; Mu, R.; Doho, G.H.; Pistolic, J.; et al. Modulation of the TLR-Mediated Inflammatory Response by the Endogenous Human Host Defense Peptide LL-37. J. Immunol. 2006, 176, 2455-2464. [CrossRef]

59. Kim, W.H.; Lillehoj, H.S.; Min, W. Evaluation of the Immunomodulatory Activity of the Chicken NK-Lysin-Derived Peptide cNK-2. Sci. Rep. 2017, 7, 45099. [CrossRef]

60. Van Opdenbosch, N.; Lamkanfi, M. Caspases in Cell Death, Inflammation, and Disease. Immunity 2019, 50, 1352-1364. [CrossRef]

61. Ramirez, M.L.G.; Salvesen, G.S. A primer on caspase mechanisms. Semin. Cell Dev. Biol. 2018, 82, 79-85. [CrossRef]

62. Ponder, K.G.; Boise, L.H. The prodomain of caspase-3 regulates its own removal and caspase activation. Cell Death Discov. 2019, 5, 56. [CrossRef]

63. Xia, Y.; Bin, P.; Liu, S.; Chen, S.; Yin, J.; Liu, G.; Tang, Z.; Ren, W. Enterotoxigenic Escherichia coli infection promotes apoptosis in piglets. Microb. Pathog. 2018, 125, 290-294. [CrossRef]

64. Kim, J.; Xu, M.; Xo, R.; Mates, A.; Wilson, G.; Pearsall, A.; Grishko, V. Mitochondrial DNA damage is involved in apoptosis caused by pro-inflammatory cytokines in human OA chondrocytes. Osteoarthr. Cartil. 2010, 18, 424-432. [CrossRef]

65. Grunnet, L.G.; Aikin, R.; Tonnesen, M.F.; Paraskevas, S.; Blaabjerg, L.; Størling, J.; Rosenberg, L.; Billestrup, N.; Maysinger, D.; Mandrup-Poulsen, T. Proinflammatory Cytokines Activate the Intrinsic Apoptotic Pathway in $\beta$-Cells. Diabetes 2009, 58, 1807-1815. [CrossRef] [PubMed]

66. Zhang, J.; Yang, Y.; Teng, D.; Tian, Z.; Wang, S.; Wang, J. Expression of plectasin in Pichia pastoris and its characterization as a new antimicrobial peptide against Staphyloccocus and Streptococcus. Protein Expr. Purif. 2011, 78, 189-196. [CrossRef] [PubMed]

67. Feng, X.; Liu, C.; Guo, J.; Song, X.; Li, J.; Xu, W.; Li, Z. Recombinant expression, purification, and antimicrobial activity of a novel hybrid antimicrobial peptide LFT33. Appl. Microbiol. Biotechnol. 2012, 95, 1191-1198. [CrossRef]

68. Deng, X.; Cao, M.; Zhang, J.; Hu, K.; Yin, Z.; Zhou, Z.; Xiao, X.; Yang, Y.; Sheng, W.; Wu, Y.; et al. Hyaluronic acid-chitosan nanoparticles for co-delivery of MiR-34a and doxorubicin in therapy against triple negative breast cancer. Biomaterials 2014, 35, 4333-4344. [CrossRef] [PubMed]

69. Kusminski, C.M.; Park, J.; Scherer, P.E. MitoNEET-mediated effects on browning of white adipose tissue. Nat. Commun. 2014, 5, 3962. [CrossRef] [PubMed]

70. Livak, K.J.; Schmittgen, T.D. Analysis of relative gene expression data using real-time quantitative PCR and the $2^{-\Delta \Delta C t} \mathrm{Method}$. Methods 2001, 25, 402-408. [CrossRef] 